\title{
The Effects of Stocking Density on Some Blood Stress Parameters of Meat Turkeys
}

\author{
Sabri Arda Eratalar ${ }^{1 *} \quad$ Rüveyde Akbay ${ }^{2}$ \\ ${ }^{1}$ Department of Poultry Science, Faculty of Agriculture and Natural Sciences, Abant İzzet Baysal University, Bolu, \\ Turkey \\ ${ }^{1}$ Department of Animal Science, Faculty of Agriculture, Ankara University, Ankara, Turkey
}

Received: 15.06.2017 Accepted: 25.07.2017

\begin{abstract}
Keywords:
Turkey, stress, welfare, blood parameters
\end{abstract}

\section{*Corresponding author}

ardaeratalar@ibu.edu.tr

\begin{abstract}
Stocking density is one of the important issues in turkey meat production which is enjoyed by consumers as a source of animal protein. This issue is examined in terms of both animal welfare and efficiency in this research. The commercial hybrid white broiler turkey line Hybrid Converter poults were individually numbered following hatch. Study took place on 200 poults. 25 males and 25 females were set in 4 different floor sized cages according to sex. Slaughter age weights in those cages were set to be $30,40,50$ and $60 \mathrm{~kg} \mathrm{~m}^{-2}$ respectively. Blood was collected in $2^{\text {nd }}$ and $6^{\text {th }}$ weeks and slaughter ages of 16 weeks for females and 20 weeks for males. Blood laboratory analyses were made after collection where each numbered individual in the pens was taken as a replicate. Findings obtained from the study were interpreted for animal welfare and economic issues based on general practice and stress level in the world and our country by subjecting statistical analysis. Stress on the poults have been found to be increasing depending on increasing stocking density and it was concluded that it would be appropriate in terms of animal welfare and ethical conviction for not exceeding certain limits of stocking density within terms of efficiency.
\end{abstract}

\section{Etlik Hindilerde Yerleşim Sıklığının Bazı Kan Stres Parametrelerine Etkileri}

\begin{tabular}{|c|c|c|}
\hline \multicolumn{2}{|l|}{ Anahtar kelimeler: } & Özet. Yerleşim sıklığı, dünyada ve ülkemizde sevilerek tüketilen bir hayvansal protein \\
\hline $\begin{array}{l}\text { Hindi, stres, refah, } \\
\text { parametreleri }\end{array}$ & kan & $\begin{array}{l}\text { kaynağı olan hindi eti üretiminde üzerinde durulan önemli konulardan birisidir. Bu } \\
\text { konu, hem hayvan refahı bakımından incelenmekte, hem de genel performans ve } \\
\text { verimlilik bakımından değerlendirilmektedir. Bu araştırmada, konu iki açıdan da } \\
\text { değerlendirilmeye çalışılmıştır. Çalışmada ticari melez hatlardan Hybrid Converter } \\
\text { beyaz etlik hindi palazları, yumurtadan çıkışı takiben numaralandırılarak kullanılmıştır. } \\
\text { Çalışma } 200 \text { adet hindi palazı üzerinde yapılmış olup kesim yaşında metrekareye 30, } \\
40,50 \text { ve } 60 \text { kg canlı ağırık gelecek şekilde farklı ebatlarda yapılmış bölmelere erkek } \\
\text { ve dişi ayrı olmak üzere, } 25 \text { 'er adet palaz yerleştirilmiştir. } 2 \text {. Haftalık yaşta hayvanlar bu } \\
\text { bölmelere alınarak yerleşim sıklığı etkisi ortaya çıkarılmıştır. Kan alım işlemi } 2 \text {. ve } 6 \text {. } \\
\text { hafta ile kesim yaşında yapılmış olup, analizler bakımından her bir birey yetiştirildiği } \\
\text { şartlar altında tekerrür olarak değerlendirilmiştir. Çalışmadan elde edilen bulgular } \\
\text { istatistik analize tabi tutularak, dünyada ve ülkemizdeki genel uygulama ve stres } \\
\text { düzeyine bağlı hayvan refahı bakımından değerlendirilmiştir. Hindilerde stresin } \\
\text { yerleşim sıklığının artışına bağlı olarak yükseldiği tespit edilmiş, hayvan refahı ve } \\
\text { verimlilik bakımından belirli sınırların aşımamasının etik olarak uygun olacağı } \\
\text { sonucuna varılmıştır. }\end{array}$ \\
\hline
\end{tabular}




\section{INTRODUCTION}

Turkey meat production is an important branch in the poultry meat industry in Turkey as it is in the world. As the world's population grows, demand for animal protein increases more than the production does. As the world's population was 6.127 Million in 2000, the turkey meat production was 5.061 Mton worldwide, where the population went up to 7.052 Million as the production just increased to 5.609 Mton. This shows the increasing output gap for protein coming from turkey meat in the world and in Turkey as it can clearly be seen on figure 1 representing the population and production change from 2000 to 2012 (FAO 2015; TUIK 2016).

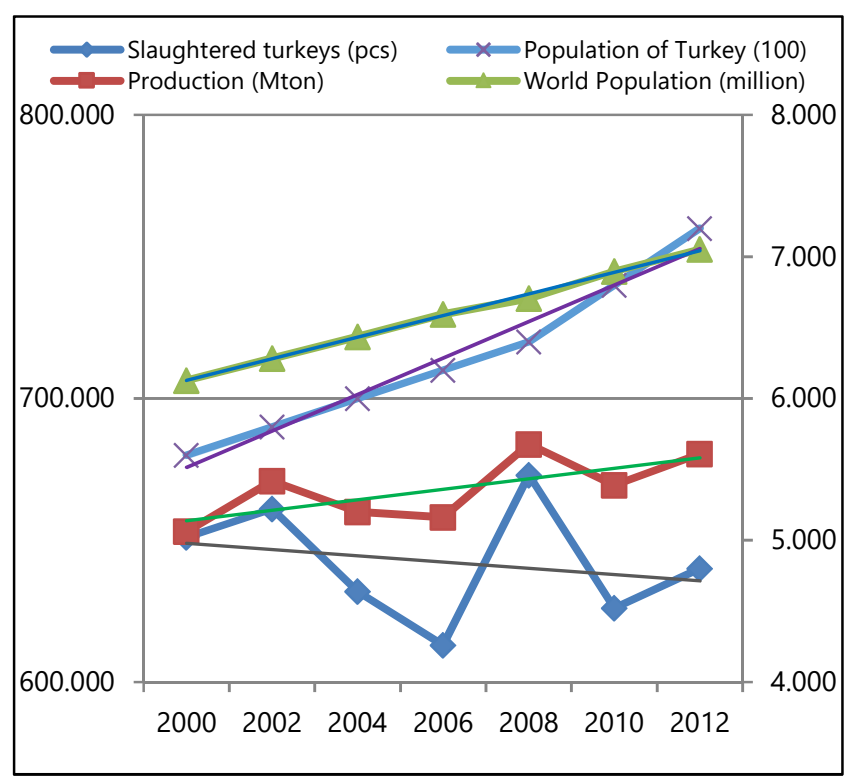

Figure 1. Turkey, World Population and turkey meat production from 2000 to 2012 (FAO 2015; TUIK 2016).

Şekil 1. 2000 - 2012 yılları arasında Türkiye'de ve dünyada hindi eti üretim miktarları.

Turkey meat is a nutritive and precious source of animal protein as seen on Table 1. It has a delicious unique aroma and taste as well. The protein level is similar to cows but less in fat. This makes turkeys a better option for people on a diet (Eratalar and Bulut 2007) as seen on Table 1.

Table 1. Nutritional value of $100 \mathrm{~g}$ meat from different farm animals (Ertugrul 1997; Ergün et al., 2001).

Çizelge 1. Farklı çiftlik hayvanlarına ait $100 \mathrm{~g}$ etin besin değeri.

\begin{tabular}{lllll}
\hline & Broiler & Turkey & Cattle & Lamb \\
\hline Energy $\left(\mathrm{kcal} \mathrm{kg}^{-1}\right)$ & 215 & 160 & 194 & 228 \\
Protein $(\mathrm{g})$ & 18.6 & 20.4 & 20.0 & 14.0 \\
Fat $(\mathrm{g})$ & 15.1 & 8.0 & 12.0 & 18.0 \\
\hline
\end{tabular}

In Turkey, public request is mostly leg and wing meat of poultry where European countries and United States mostly demand on breast meat. This may give Turkey an option of selling wings and legs in the country and exporting breast meat to Europe soon for a better profit. Meanwhile, it should be taken into consideration to make more advertisements to achieve a better community understanding of how healthy turkey meat is.

Turkeys can only show their genetic potential of growth and meat yield under the best environmental conditions. In the production farms, stocking density is one of the most important primary factors affecting the birds' performance as well as lighting, ventilation and optimum heating.

Surely, animal ethics and welfare should be taken into consideration when organizing the optimum stocking density for production with economical aspects.

In a research, Noll et al. (1991) set 2.2 and 4.8 male turkeys per square meters. Researchers arrived at the data that the birds at higher stocking density had less live weight than the others. As well, a supporting research result comes from Dogrul et al. (2005). Researchers have designed a work with 3 and 4 birds $\mathrm{m}^{-2}$ and concluded that birds reared at higher stocking density (SD) resulted in worse growth performance.

Also Mirabito et al. (2002) shares the data that decreasing the levels of stocking density brings no difference in performance and health issues but worsens the economic aspects in production. Hafez and Hagen (2003) also showed that there is no significant difference between SD groups for turkey poults in terms of health and immune response. Cetin and Ogan (1997) reported that increasing stocking density conditions made the antibody titers fall after vaccination in broiler chickens. Houshmand et al. (2012) found that there has been no difference between stocking density groups of 10 and 16 broiler chickens $\mathrm{m}^{-2}$ on blood glucose levels and $\mathrm{H} / \mathrm{L}$ ratios. In contrast Qaid et al. (2016) found that except blood glucose levels stress indicators as decreasing $\mathrm{H} / \mathrm{L}$ levels and increasing heterophyl levels showed that there is an impact of stocking density on stress of the broiler chickens. Azzam and Gogary (2015) also reported that there has been no change on blood glucose levels of chickens reared at stocking densities of 11.90 birds $\mathrm{m}^{-2}$ and 16.66 birds $\mathrm{m}^{-2}$.

As stress indicators, blood glucose, lymphocyte count, leukocyte count, heterophyl count and Heterophyl/Lymphocyte $(H / L)$ ratio were by Maxwell 
et al. (1990), Martrenchar et al. (1997), Patterson and Siegel (1998) and Houshmand et al. (2012).

As seen there have been several researches about SD for chickens and turkeys. But, there is no similarity for these researches for bird races, SD levels, environmental conditions etc. This research is important for introducing the present condition for determining the stocking density effect on stress levels of turkeys in contrast to turkey production in Turkey.

\section{MATERIALS AND METHODS}

The animal material of the research was obtained from Bolca Hindi which is a turkey meat production company integration founded in Bolu, Turkey. The hatching eggs were obtained from 42 week old Hybrid Converter breeders which were reared in the same breeder house. 200 hatching eggs of these breeders were hatched in the company's hatchery and were transferred to the production farm of the company immediately after automatic vaccination, sexing and beak trimming at the hatchery. The birds were randomly aluminum wing banded, numbered from 1 200. So, all the birds would be personally tested as a replicate for the connected blood parameters.

Research took place in commercial company's turkey farm and cages were built in before the research was set. Female cages were $8.245 \mathrm{~m}^{2}, 6.179$ $\mathrm{m}^{2}, 4.943 \mathrm{~m}^{2}$ and $4.125 \mathrm{~m}^{2}$ for $30,40,50$ and $60 \mathrm{~kg} \mathrm{~m}^{-}$ ${ }^{2}$ estimated live weight at the slaughter age of the birds. Male cages were $15.443 \mathrm{~m}^{2}, 11.575 \mathrm{~m}^{2}, 9.363 \mathrm{~m}^{2}$ and $7.727 \mathrm{~m}^{2}$ for $30,40,50$ and $60 \mathrm{~kg} \mathrm{~m}^{-2}$ estimated slaughter weight of the poults.

Birds were placed in 8 pens 4 male pens and 4 female pens with 25 birds in each pen. In the first 2 weeks birds were reared in rings for better start and the rings were removed at the $2^{\text {nd }}$ week. So, the SD (stocking density) effect was put on in the $2^{\text {nd }}$ week. The SD levels were arranged for the birds' estimated slaughter weights of $30,40,50$ and $60 \mathrm{~kg} \mathrm{~m}^{-2}$.

The slaughter weights (SW) of the birds came up higher but not more than $2.5 \%$ than the estimated SW set at the beginning of the study.

Vaccination program for the birds used by the company is shown at Table 2.

Male birds were fed with 8 different types of feed where females were fed with 7 different feed in the rearing period. Males were slaughtered at the $20^{\text {th }}$ week where females were at $16^{\text {th }}$ week which were the suitable and the present application at the time of the study.

Feed and water were given ad-libitum. All the feed were obtained from Bolca Hindi's feed mill. The chemical and physical composition of the feed is shown in Table 3.

Lighting program was the same for all the birds with a beginning of 100 lux florescent light at bird level and after $2^{\text {nd }}$ day dark period began with 30 minutes and increased 30 minutes every day up to 6 hours of dark and 18 hours of light which was continued till the end of the rearing period. 100 lux was decreased to 75 lux at day 7 and it was decreased to 50 lux at the $2^{\text {nd }}$ week and went on till slaughter age.

The poults arrived at the farm were reared at $37.0 \pm 0.5^{\circ} \mathrm{C}$ and the temperature was decreased $0.5^{\circ} \mathrm{C}$ daily till the rearing environment is finally $20.0^{\circ} \mathrm{C}$ and this temperature $\left(20.0^{\circ} \mathrm{C} \pm 0.5^{\circ} \mathrm{C}\right)$ was kept till the slaughter age.

Proper ventilation was obtained by an automatic environment control system controlling the side curtains during the whole period of the study.

Health control was done by the company's veterinarian where no drugs and feed additives were used during the study.

The bedding material was disinfected, dry pinewood shavings which was spread about $5 \mathrm{~kg} \mathrm{~m}^{-2}$ to the ground homogeneously.

Blood sampling was done in $2^{\text {nd }}, 6^{\text {th }}$ weeks and at the slaughter age of $16^{\text {th }}$ week for females and $20^{\text {th }}$ week for males. Blood was taken by veterinarian of the company and $2.5 \mathrm{cc}$ sterile single use injectors were used with green tip needles. 2 cc bloods were taken from each bird and were transferred into $3 \mathrm{ml}$ EDTA tubes containing EDTA for the blood not to coagulate until reaching the lab. Samples were taken from a total of 40 and 10 birds of each stocking density group. The bloods were immediately taken to the lab in an environment controlled carrying box. Blood sugar, leucocyte, erythrocyte, hemoglobin, thrombocyte, lymphocyte counts were taken, hematocrit value and erythrocyte volume was determined by the private laboratory experts with suitable experimental blood kits for poultry.

Table 2. The vaccination program used in the experiment. Çizelge 2. Denemede kullanılan aşılama programı.

\begin{tabular}{lcccc}
\multicolumn{1}{c}{ Time } & Vaccine & Type & Method & The disease \\
\hline After hatch & HB1 & Active & Spray & Newcastle D. \\
7. Day & TRT & Active & Spray & TRT \\
Clone & & & \\
21. Day & 30 & Active & Spray & Newcastle D. \\
35. Day & TRT & Active & Spray & TRT \\
56. Day & Lasota & Active & Spray & Newcastle D. \\
\hline
\end{tabular}


Table 3. Feeds' chemical and physical contents for the rearing period.

Çizelge 3. Yetiştirme dönemi boyunca kullanılan yemin fiziksel ve kimyasal özellikleri.

\begin{tabular}{lcccccccc}
\hline Feed No & $\mathbf{3 0 1}$ & $\mathbf{3 0 2}$ & $\mathbf{3 0 3}$ & $\mathbf{3 0 4}$ & $\mathbf{3 0 5}$ & $\mathbf{3 0 6}$ & $\mathbf{3 0 7}$ & $\mathbf{3 0 8}$ \\
\hline Weeks & $0-2$ & $2-4$ & $4-6$ & $7-9$ & $10-12$ & $13-14$ & $15-16$ & $17+$ \\
Crude protein (\%) & 28.5 & 27.5 & 26 & 23.5 & 21.5 & 19.5 & 18 & 17 \\
ME (kcal kg ${ }^{-1}$ ) & 2750 & 2850 & 2950 & 3050 & 3125 & 3225 & 3350 & 3400 \\
Methionine & 0.74 & 0.69 & 0.63 & 0.56 & 0.5 & 0.44 & 0.4 & 0.37 \\
Meth. + Syst. & 1.21 & 1.17 & 1.07 & 1.0 & 0.9 & 0.8 & 0.72 & 0.68 \\
Lysine & 1.85 & 1.8 & 1.66 & 1.55 & 1.4 & 1.2 & 1.02 & 0.9 \\
Calcium & 1.45 & 1.4 & 1.4 & 1.3 & 1.2 & 1.1 & 1.0 & 1.0 \\
Digestible & 0.78 & 0.75 & 0.75 & 0.65 & 0.6 & 0.55 & 0.5 & 0.5 \\
Phosphorus & 0.17 & 0.17 & 0.17 & 0.18 & 0.18 & 0.18 & 0.18 & 0.18 \\
Sodium & 1.11 & 1.1 & 1.04 & 1.0 & 0.93 & 0.76 & 0.64 & 0.58 \\
Threonine & 0.34 & 0.3 & 0.27 & 0.25 & 0.23 & 0.2 & 0.18 & 0.17 \\
Tryptophan & 1.98 & 1.94 & 1.79 & 1.63 & 1.44 & 1.24 & 1.05 & 0.93 \\
Arginine & Crumble & Pellet & Pellet & Pellet & Pellet & Pellet & Pellet & Pellet \\
Structure of the & & & & & & & & \\
feed & & & & & & & &
\end{tabular}

The data achieved from blood sampling and analyses were computed with Minitab 14 statistical analysis software program using variance analysis and Duncan Test (Düzgüneş et al., 1987; Sheskin 2000; Minitab 2014).

The non-homogeneous data of blood parameters were transformed using square root transformation $Y$ $=\sqrt{ } \mathrm{P}$ equality. All blood samples were analyzed separately by a linear model as shown below.

$$
Y_{i j}=\mu+\alpha_{i}+e_{i j}
$$

$Y_{i j}: i^{\text {th }}$ stocking density group, $j^{\text {th }}$ week observed value $\mu$ : population mean for the blood parameter

$\alpha_{i}: i^{\text {th }}$ stocking density group effect

$e_{i j}:$ random error

\section{RESULTS AND DISCUSSION}

The findings of the research suggests that blood glucose levels of female turkeys are not affected by the SD at 6 weeks of age where male turkeys are at the same age as seen on Tables 4 and 5 respectively. As another outcome, blood glucose levels of female turkeys have changed statistically at the age of slaughter where males were not affected at the slaughter age. This consequence may have come forth because males were slaughtered at the age of 20 weeks where females were at 16 weeks. So, by the passing 4 weeks males may have overcome stress and may not have showed any indicator at the slaughter age after 16 weeks.

The findings of the research are in harmony of the results of the research made by Khadjeh et al. (2004) on local turkeys. They found BC (Blood Glucose) levels of $342.3 \pm 152.6 \mathrm{~g} 100 \mathrm{ml}^{-1}$. Assuming the standard deviation these findings are numerically similar as seen.

Table 4. Blood glucose levels of female turkeys reared under different SDs.

Çizelge 4. Farklı yerleşim sıklıklarında yetiştirilen dişi hindilerde kan şeker düzeyleri.

\begin{tabular}{|c|c|c|c|}
\hline \multirow{2}{*}{ 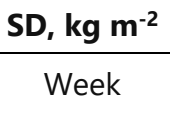 } & \multicolumn{3}{|c|}{ Blood glucose Levels, g $100 \mathrm{ml}^{-1}(\bar{X} \pm \mathrm{S} \bar{X})$} \\
\hline & 2 (start) & 6 & 16 \\
\hline 60 & $274.79 \pm 4.44$ & $290.18 \pm 6.04$ & $294.18 \pm 2.48^{a}$ \\
\hline 50 & $276.18 \pm 4.36$ & $293.87 \pm 3.38$ & $174.31 \pm 5.32^{\mathbf{b}}$ \\
\hline 40 & $271.72 \pm 1.66$ & $296.06 \pm 2.63$ & $282.34 \pm 12.73^{a}$ \\
\hline 30 & $266.40 \pm 4.67$ & $297.70 \pm 3.41$ & $195.54 \pm 8.03^{b}$ \\
\hline$S \bar{x}$ & 2.00 & 2.01 & 9.24 \\
\hline $\mathrm{F}$ & 1.19 & 0.63 & 56.05 \\
\hline$P$ & $>0.05$ & $>0.05$ & $<0.01$ \\
\hline
\end{tabular}

The statistically different data is shown as small uppercase characters and $\mathrm{P}$ values are as given. (SD: Stocking Density).

As another outcome of the experiment, Lymphocyte counts (LC) were found to be changing during the lifespan of the birds. At slaughter age, LC was found to be higher in both male and female birds reared at a SD of 30 and $40 \mathrm{~kg} \mathrm{~m}^{-2}$. Also at 6 weeks where LC of females were not significantly different, LC of males were found to be significantly different as birds reared at lower SD levels had higher LC levels. Decreasing $L C$ shows the stress on the birds reared on higher SD. However there has been no other parameter backing up the statistically important differences in LC, itself can be told to be an indicator of stress as the increasing $\mathrm{H} / \mathrm{L}$ ratio which may occur 
by decreasing LC by itself Gross and Siegel (1983). LC values can be seen on Table 6 .

Table 5. Blood glucose levels of male turkeys reared under different SDs.

Çizelge 5. Farklı yerleşim sıklıklarında yetiştirilen erkek hindilerde kan şeker düzeyleri.

\begin{tabular}{|c|c|c|c|}
\hline SD, $\mathrm{kg} \mathrm{m}^{-2}$ & \multicolumn{3}{|c|}{ Blood glucose levels, g $100 \mathrm{ml}^{-1}(\bar{X} \pm S \bar{X})$} \\
\hline Week & 2 (start) & 6 & 20 \\
\hline 60 & $272.69 \pm 1.59$ & $291.43 \pm 5.79^{a b}$ & $268.17 \pm 7.89$ \\
\hline 50 & $272.03 \pm 2.81$ & $304.71 \pm 6.69^{a}$ & $281.49 \pm 14.64$ \\
\hline 40 & $278.64 \pm 4.12$ & $286.19 \pm 5.31^{b}$ & $251.43 \pm 13.94$ \\
\hline 30 & $278.94 \pm 3.90$ & $289.85 \pm 4.28^{a b}$ & $257.17 \pm 3.78$ \\
\hline$s \bar{x}$ & 1.63 & 2.91 & 5.6 \\
\hline $\mathrm{F}$ & 1.34 & 2.09 & 1.45 \\
\hline$P$ & $>0.05$ & $<0.05$ & $>0.05$ \\
\hline
\end{tabular}

The statistically different data is shown as small uppercase characters and $\mathrm{P}$ values are as given. (SD: Stocking Density).

As it is specified by some researchers (Maxwell et al., 1990, Martrenchar et al., 1997) $\mathrm{H} / \mathrm{L}$ ratio is a stress indicator for poultry. The increase in $\mathrm{H} / \mathrm{L}$ ratio is known to be the indication of stress and the inclination of this parameter numerically is told to be because of the drop in lymphocyte counts where stress is imminent. As it can be seen on the Tables 6 and 7 the stress on turkeys are increasing especially on females and there is a permanent stress on birds during the whole rearing period where the SD effect is actual.

\section{CONCLUSION}

Stress is one of the main points of animal welfare. In Turkey birds are reared under stocking densities of

Table 6. Lymphocyte count of female turkeys reared under different SDs.

Çizelge 6. Farklı yerleşim sıklıklarında yetiştirilen dişi hindilerde lenfosit sayıları

\begin{tabular}{|c|c|c|c|}
\hline \multirow{2}{*}{$\frac{\text { SD, } \mathbf{~ k g ~ m}^{-2}}{\text { Week }}$} & \multicolumn{3}{|c|}{ Lymphocyte levels, g $100 \mathrm{ml}^{-1}(\bar{X} \pm S \bar{X})$} \\
\hline & 2 (start) & 6 & 16 \\
\hline 60 & $81.44 \pm 3.96^{a}$ & $88.18 \pm 2.36$ & $72.48 \pm 0.74^{\mathbf{b}}$ \\
\hline 50 & $78.53 \pm 4.22^{a}$ & $100.00 \pm 0.01$ & $73.17 \pm 2.57^{b}$ \\
\hline 40 & $73.26 \pm 3.76^{\mathrm{ab}}$ & $92.9 \pm 2.68$ & $88.37 \pm 2.10^{a}$ \\
\hline 30 & $64.24 \pm 3.40^{\mathrm{ab}}$ & $90.65 \pm 8.45$ & $96.38 \pm 5.09^{a}$ \\
\hline$S \bar{x}$ & 2.12 & 2.31 & 2.19 \\
\hline $\mathrm{F}$ & 4 & 1.35 & 15.12 \\
\hline$P$ & $<0.05$ & $>0.05$ & $<0.01$ \\
\hline
\end{tabular}

The statistically different data is shown as small uppercase characters and $\mathrm{P}$ values are as given. (SD: Stocking Density).
Table 7. Lymphocyte count of male turkeys reared under different SDs.

Çizelge 7. Farklı yerleşim sıklıklarında yetiştirilen erkek hindilerde lenfosit sayıları.

\begin{tabular}{cccc}
\hline SD, $\mathbf{~ g ~ ~}^{-\mathbf{2}}$ & \multicolumn{3}{c}{ Lymphocyte levels, $\mathbf{~} \mathbf{1 0 0} \mathbf{~ m l}^{\mathbf{- 1}}(\overline{\mathrm{X}} \pm \mathbf{S} \overline{\mathrm{X}})$} \\
\hline Week & 2 (start) & 6 & 20 \\
60 & $79.01 \pm 4.31$ & $57.04 \pm 5.27^{\mathbf{d}}$ & $62.12 \pm 0.37^{\mathrm{ab}}$ \\
50 & $74.98 \pm 7.12$ & $80.47 \pm 0.90^{\mathbf{c}}$ & $57.73 \pm 3.89^{\mathbf{b}}$ \\
40 & $70.04 \pm 5.37$ & $96.93 \pm 1.78^{\mathrm{b}}$ & $66.11 \pm 0.84^{\mathrm{a}}$ \\
30 & $65.95 \pm 3.72$ & $108.80 \pm 1.59^{\mathrm{a}}$ & $65.15 \pm 2.85^{\mathrm{a}}$ \\
$\mathrm{S} \bar{X}$ & 2.66 & 3.41 & 1.29 \\
$\mathrm{~F}$ & 1.2 & 46.61 & 2.59 \\
$\mathrm{P}$ & $>0.05$ & $<0.01$ & $<0.05$
\end{tabular}

The statistically different data is shown as small uppercase characters and $\mathrm{P}$ values are as given. (SD: Stocking Density).

40-50 $\mathrm{kg} \mathrm{m}^{-2}$. The experiment was designed to evaluate the current situation in the country on the term of stress and to find out if there is a change in stress on animals by SD if the SD is increased or decreased.

As it is told by many researchers, the main stress parameters are $B C, L C$ and $H / L$ ratios where mainly $B C$ and LC specify the stress (Maxwell et al., 1990; Martrenchar et al., 1997).

In the experiment LC counts were found to be decreasing in parallel with the increasing SD levels. The stress on animals can be seen during the whole rearing period where $L C s$ were found to be higher in lower SDs and less at higher SDs of 50 and $60 \mathrm{~kg} \mathrm{~m}^{-2}$ as it can be seen on Tables 6 and 7 .

Also, $B C$ was found to be higher in various periods of rearing period on higher SDs. This is also a sign of stress on birds just as LC counts demonstrate.

As a summary it can be said that the stress on turkey broilers tends to increase with the increase in SDs. The break point of incipience of stress seems to be between $40-50 \mathrm{~kg} \mathrm{~m}^{-2}$ SDs and there should be further and more detailed researches should be undertaken to determine the point of commencing stress as a SD level. So this level should be used as a barrier for animal welfare as a limiting parameter.

From the outcome of the research it can surely be told that in terms of animal welfare and stress the amount of stress on turkey broilers increase at higher SDs. However, there has been no significant change on performance parameters during the research of turkeys reared under different SDs, stress have been ongoing for the whole rearing period which should be taken into consideration as an animal welfare aspect. 


\section{ACKNOWLEDGEMENT}

As a consultant during the entire Ph. D. period and during the research I give very special thanks to Prof. Dr. Rüveyde AKBAY. I wish to see many more scientists like her who will contribute to the promotion of our country and to the scientific community at such a high level.

\section{REFERENCES}

Azzam MMM and Gogary MREl., 2015. Effects of dietary threonine levels and stocking density on the performance, metabolic status and immunity of broiler chickens. Asian Journal of Animal and Veterinary Advances, 10(5): 215-225.

Çetin C and Oğan M., 1997. Broiler piliçlerde farklı yerleşim sıklıklarının humoral immün yanıt üzerine etkisi. Veterinarium, 8(1-2): 78-80.

Doğrul M., Demir H and Ekiz B., 2005. Farklı yerleşim sıklığında yetiştirilen erkek hindilerin besi performansı ve karkas özellikleri. İstanbul Üniversitesi Veteriner Fakültesi Dergisi, 31(2): 113-131.

Düzgüneş O., Kesic T., Kavuncu O and Gürbüz F., 1987. Araştırma ve deneme metotları. Ankara Üniversitesi Ziraat Fakültesi Yayınları No:1021, Ankara.

Eratalar SA and Bulut O., 2007. Türkiye'de hindi yetiştiriciligi. Veteriner Tavukçuluk Derneği Dergisi, 5(3): 11-19.

Ergün A., Tuncer ŞD., Çolpan İ., Yalçın S., Yıldız G., Küçükersan MK., Küçükersan S and Şehu A., 2001. Hayvan besleme ve beslenme hastalıkları. Medipres, Ankara.

Ertugrul M., Akman, N., Aşkın, Y., Cengiz, F., Ertugrul, M., Fıratlı, Ç., Türkoglu $M$ and Yener M., 1997. Hayvan yetiştirme (yetiştiricilik). Baran Ofset, Ankara.

FAO 2015. Livestock production http://www.fao.org/docrep/005/y4252e/y4252e07.htm. [Access: 07 November 2016].

Gross WB and Siegel HS., 1983. Evaluation of the heterophyl: lymphocyte ratio as a measure of stress in chickens. Avian Diseases, 27: 972-979.

Hafez HM and Hagen N., 2003. Influence of stocking density on health condition in meat turkey flocks under field conditions. Turkey Production: Balance Act between Consumer Protection, Animal Welfare and Economic Aspects, Berlin.
Houshmand M., Azhar K., Zulkifli I., Bejo MH and Kamyab A., 2012. Effects of prebiotic, protein level and stocking density on performance, immunity and stress indicators of broilers. Poultry Science, 91: 393-401.

Khadjeh GH., Mayahi M., Jalali MR. and Rasekh AR., 2004. Reference values of some blood serum biochemical parameters. XXII. World's Poultry Congress, 8-13 June 201, Istanbul.

Martrenchar A., Huonnic JP., Cotte JP, Boilletot E and Morisse JP., 1997. Influence of stocking density on some behavioral, physiological and productivity traits of broilers. Veterinary Research, 28: 473-480.

Maxwell MH., Robertson GW., Spence S and McCorquadale CC., 1990. Comparison of hematological values in restricted and ad-libitum fed domestic fowls: white blood cells and thrombocytes. British Poultry Science, 31: 399-405.

MINITAB 14 2004. Statistical Software. Minitab Inc. Quality Plaza, 1829 Pine Hall Road State College, PA 16801-3008, USA.

Mirabito L., Barthelot A., Baron F., Bouvarel L., Aubert C., Bocquier C., Dalibard F., Sante V and Pottier G., 2002. Influence of reducing the stocking density of the performance, behavior and physical integrity of meat turkeys. 11. European Poultry Conference, 26-28 May 2016, Berlin.

Noll SL., Halawani MEE., Waibel PE., Redig P and Janni K., 1991. Effect of diet and population density on male turkeys under various environmental conditions. 1. Turkey growth and health performance. Poultry Science, 70: 923-934.

Patterson PH and Siegel HS., 1998. Impact of cage density on pullet performance and blood parameters of stress. Poultry Science, 77: 32-40.

Qaid M., Albatshan H., Shafey T., Hussein E and Abudabos AM., 2016. Effect of stocking density on the performance and immunity of 1-14-d-old broiler chicks. Brasilian Journal of Poultry Science, 18(4): 683-691.

Sheskin DJ., 2000. Handbook of parametric and nonparametric statistical procedures (second edition). Western Connecticut University. Chapman \& Hull, USA.

TUIK 2016. Hayvansal üretim istatistikleri. ttp://www.tuik.gov.tr/PreHaberBultenleri.do?id $=21871$. [Access: 07 September 2016]. 